\title{
Key factors influencing the mechanism of rapid and long runout landslides triggered by the 2008 Wenchuan earthquake, China
}

\author{
Fawu Wang ${ }^{1 *}$, Ping Sun ${ }^{2}$, Lynn Highland ${ }^{3}$ and Qiangong Cheng ${ }^{4}$
}

\begin{abstract}
Background: The 2008 Wenchuan earthquake triggered many rapid and long runout landslides, which directly caused great loss of property and human lives and were responsible for a large percentage of total damages caused by the earthquake. It is very important for the purposes of landslide disaster prevention and mitigation to understand the earthquake triggered mechanism of initiation and motion of rapid and long runout landslides, which can potentially be the deadliest of ground failures.
\end{abstract}

Results: In this paper, field investigations of some highly damaging landslides caused by the Wenchuan earthquake are introduced first, and followed by data from ring shear tests used to simulate the initiation and motion of one landslide in particular, the Donghekou complex landslide.

Conclusions: It was found that groundwater and valley water played key roles in the rapid motion and long runout process of this landslide during the great earthquake.

Keywords: Wenchuan earthquake; Rapid and long runout landslides; Initiation; Motion; Hydrogeological condition

\section{Background}

The Wenchuan earthquake occurred at 14:28 local Beijing time on 12 May 2008 in Sichuan Province of China (Cui et al. 2009; Huang and Li 2009). The earthquake's epicenter was located at Yingxiu Town, Wenchuan County $\left(30.40^{\circ} \mathrm{N}\right.$, $103.47^{\circ} \mathrm{E}$, and its depth was $14 \mathrm{~km}$ ). The earthquake magnitude was Mw7.9 (U.S. Geological Survey 2008) and Ms8.0 (China Earthquake Administration 2008). The most affected area was along the central and frontal faults of the Longmen Shan fault system in western Sichuan, in a $300 \mathrm{~km}$ long belt-shaped zone (Figure 1). Numerous landslides were triggered in this zone (Yin et al. 2009; Tang et al. 2009). According to Cui et al. (2009), as of 19 June 2009, the earthquake resulted in 69,200 known deaths, 18,195 missing, 374,216 injured, 5,362,500 collapsed houses, 21,426,600 badly damaged houses, and more than five million people left homeless. Among the losses and damages, about one third were due to earthquake-induced landslides (Yin et al. 2009). The large amount of damage

\footnotetext{
* Correspondence: wangfw@riko.shimane-u.ac.jp

'Department of Geoscience, Shimane University, Matsue, Japan

Full list of author information is available at the end of the article
}

from landslides results from a combination of factors that include a large magnitude earthquake, topographical controls, and the population distribution of the area. This tectonically active area is characterized by steep mountains and river systems that are formed at the boundary between the Tibetan Plateau and the Sichuan Basin, making this area susceptible to erosion and landsliding (Yi et al. 2006; Burchfiel et al. 2008; Ouimet 2010). The relatively gentle topography that exists in some areas of the Longmen Shan fault system attracted people, as there is a good groundwater supply as well as a mild climate. Three county capital towns, Dujiangyan City, Qushan Town (Beichuan County), and Qiaozhuang Town (Qingchuan County) were located along the fault system, making the fault belt a densely populated area. During the earthquake, all of the county towns were severely damaged by strong shaking, fault displacement and landsliding. Among them, Qushan Town that is located in the middle part of the Longmen Shan fault system was most heavily damaged. At this site, two landslides (Chengxi slide and Xinbei Mid-school slide) destroyed everything in their travel paths, and directly caused more than 2,100 deaths in Beichuan County (Yin et al. 2009). 




Figure 1 Geography, topography and rivers of the earthquake region (Ouimet, 2010) (with permission from W Ouimet). The surface rupture associated with the Wenchuan earthquake by Xu et al. (2009) (solid lines denote inferred rupture) and aftershocks greater than M4.5 are also included. The Yingxiu, Beichuan and Pengguan faults are labeled. Four landslides mentioned in this paper are marked, and SFB strong-motion station is shown.

Analyzing the meteorological conditions just prior to the earthquake is vital for framing the explanation as to why the landslides were so large and numerous. In the earthquake affected area, there are three meteorological monitoring stations, located in Dujiangyan City, Pingwu County, and Mianyang City. The one located in Pingwu County is near the center of the earthquake affected area, and is $50 \mathrm{~km}$ west of the Donghekou complex slide, which will be described. The daily rainfall data in 2008 are shown in Figure 2, indicating that the total precipitation in 2008 was $718.5 \mathrm{~mm}$. Considering the rainfall intensity and frequency, the period from March to May can be classified as experiencing medium rainfall, while June to September can be classified as having heavy rainfall. The Wenchuan earthquake occurred during a medium rainfall season. The antecedent rainfall before the earthquake was $58.8 \mathrm{~mm}$ for one month (from 12 April to 12 May), and $33.3 \mathrm{~mm}$ for ten days (from 2 May to 12 May).

As summarized by Bird and Bommer (2004), large landslides triggered by earthquakes can potentially cause massive loss of life and injuries and leave an indiscriminate trail of devastation. In this paper, some typical landslides, which moved rapidly and caused large numbers of fatalities, will be briefly introduced and compared with each other. The examples are Xiejiadian landslide at Jiufeng in Pengzhou City, the rapid and long runout Chengxi landslides and the Xinbei Mid-school rockslide in Beichuan County, and the Donghekou complex slide in

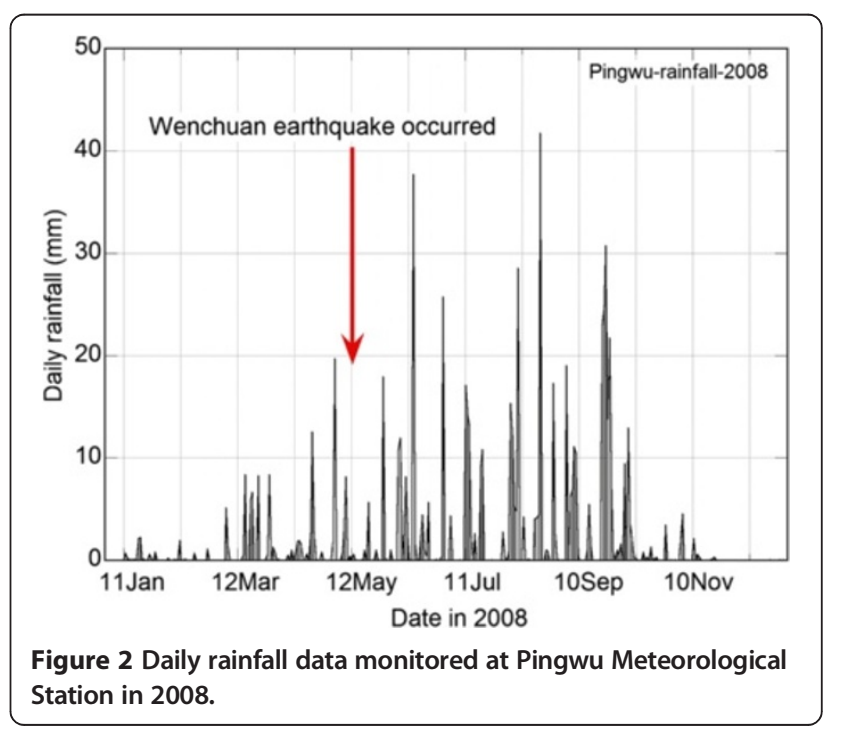


Qingchuan County (Figure 1). These landslides killed all of the people and destroyed all villages in their travel paths (Wang et al. 2009; Yin et al. 2009; Cui et al. 2009; Sato and Harp 2009). Secondly, a detailed study of the Donghekou complex landslide will be presented. The detailed study includes field investigation, soil sampling, and a geosimulation test on the soil samples from this slide, with the application of actual seismic motion from the earthquake. This study will contribute to an understanding of the mechanism of the initiation and motion of rapid and long runout landslides, especially the key factors controlling the travel distance.

\section{Methods, results and discussions \\ Field investigations for some typical landslides}

In the year following the Wenchuan earthquake, the authors investigated the earthquake affected areas for geohazards at four different points in time. The first time was in June 2008, one month after the earthquake occurred. At that time, most of the landslides remained in their original shape after initial occurrence and the local people had a recent memory about the topographic change around them, making the observation and investigation more closely attuned to conditions which occurred immediately after the initiation of the landslides. Investigations were conducted on Chengxi landslide, Xinbei Mid-school rockslide, and Xiejiadian landslide. The second investigation was conducted in July 2008. At that time, the first access to Donghekou complex slide was made. Two landslide dams caused by this slide were not yet excavated or modified. After that time, the landslide dams were leveled, and a memorial park was built at the lower part of the slide. The third investigation was conducted at the end of July 2008 for a duration of one week, and debris flows caused by rainfall in the earthquake-affected area were observed. During the fourth investigation conducted in February 2009 (a dry season in this area), it was found that groundwater was flowing out of the slide surface and source area of the Chengxi landslide, the Donghekou complex slide, and the Xiejiadian landslide. During the field investigations, there was a strong indication that the hydrogeological conditions associated with the landslides controlled the initiation and motion of the landslides. In order to verify this hypothesis, characteristics of some of these typical landslides, i.e., the Xiejiadian landslide, the Chengxi landslide and the Xinbei Midschool rockslide, and the Donghekou complex slide are presented here to show the importance of hydrogeological conditions to the landslide process.

\section{Xiejiadian rockslide - rock flow in Jiufeng Village}

In Jiufeng Village, Pengzhou City, the Xiejiadian rockslide, which occurred first, later became a flowslide since the topography of the source area made the accumulation and impounding of water possible. The head scarp of this landslide is on a steep cliff of Precambrian granite, which is located above a small valley that channeled the flow (Chigira et al. 2010). The total travel distance is about $1.6 \mathrm{~km}$, which occurred rapidly leading to more than 100 fatalities from the lack of fleeing time. In Figure 3a, the smashed houses and displaced slide mass looks very dry, and a witness did not see any water seep out from the displaced slide mass. Also, as seen in Figure $3 \mathrm{~b}$, which is an old map created before the earthquake, a gully with water has always existed in this area. In Figure 3c, the displaced slide mass consists of large gravels and boulders, and thus the permeability of the slide mass should be very high. The high permeability will not allow groundwater to be distributed throughout the sliding mass, but it will be most significant near the sliding surface. To find groundwater in the source area and the travel path, we investigated the Xiejiadian rockslide in February 2009 again. As shown in Figure 3d, it was found that groundwater flow existed at the bottom of the displaced slide debris. The surface gully where two persons were taking samples was formed by water erosion in the period between May 2008 after the earthquake and February 2009 when the investigation was carried out. According to Chigira et al. (2010), the investigators also found water-saturated clayey materials and water flow in the source area.

\section{The Chengxi complex landslide (debris fall/slide/flow) and the Xinbei Mid-school rockslide in Qushan Town}

The damages caused by landslides triggered by the Wenchuan earthquake in Qushan Town, Beichuan County are the most severe of the entire disaster (Figure 4). At the west part of Qushan Town, the Chengxi (meaning the west side of the town) complex landslide occurred. Here, debris consisting of weathered shale and sandstone moved downward at first, then slipped at the slope toe, and finally became a flow slide. It destroyed and buried all of the buildings in its travel path, which was the center of the old area of Qushan Town. Moreover, because of the landslide's extremely high speed, the buildings distributed around its deposit boundary collapsed due to the extreme force of an air-blast caused by the landslide motion. This landslide caused 1,600 fatalities.

In the fourth investigation, we confirmed that groundwater existed in the weathered shale in the source area of the landslide, and the underground soil located $30 \mathrm{~cm}$ beneath the surface had high water contents, while the surface was quite dry.

The cause of the rapid sliding in the Chengxi complex slide, in addition to the steepness of the slope at the source area, was possible due to the existence of a shallow groundwater table in the basin beneath Qushan Town. As indicated by a longitudinal cross section on 


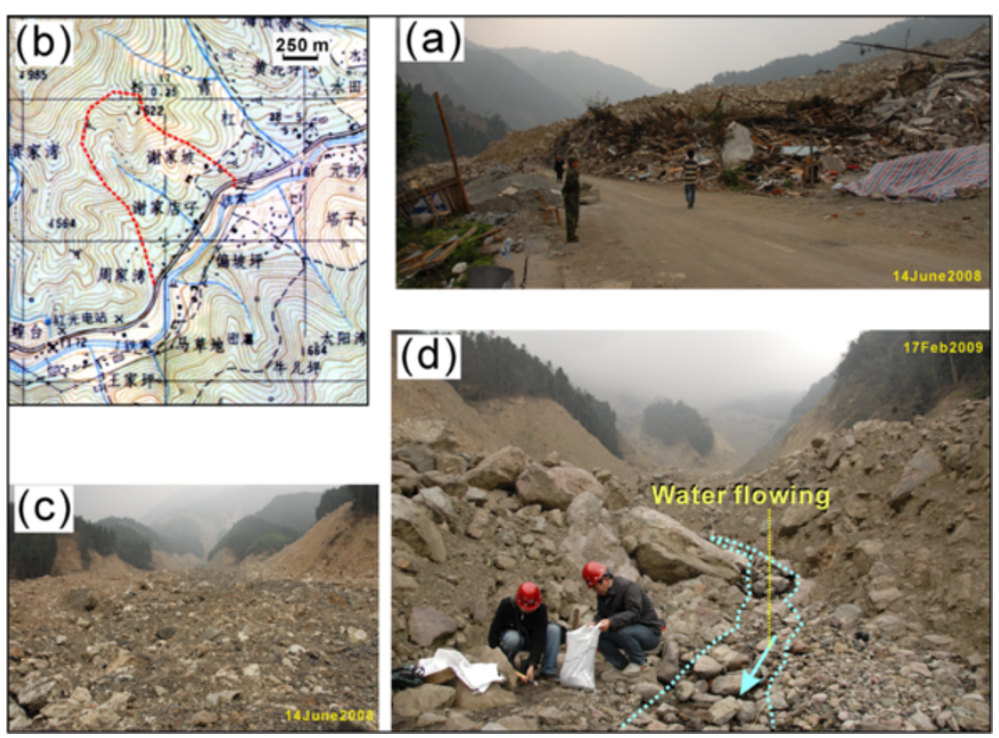

Figure 3 Photos and map of the Xiejiadian rock flow in Jiufeng Village. (a) Toe of the rock flow (taken on 14 June 2008); (b) Old map showing a valley located along the travel path; (c) Travel path of the rock flow (taken on 14 June 2008); (d) Water flowing which is fed by a groundwater discharge from the source area (Taken on 17 February 2009).

the Chengxi slide made by Yin et al. (2009), the ground level before the earthquake was just 3-5 m higher than the water level in the Jian River, a river flowing through Qushan Town. We had planned to excavate the slide mass to determine the water content in the slide surface, however, this area has been reserved for an earthquake memorial park, and we could not get permission.

The Xinbei Mid-school rockslide occurred in dolomite/ limestone. Because the displaced rock mass was almost dry and of large boulder size, it slowed and stopped at about 25 degrees. The permeability of dolomite block is high because of its fractured structure. In addition, the travel path of this slide is at a much higher elevation than the Jian River. The groundwater table is estimated to be far beneath the slide surface of the rockslide. There is no water affecting the sliding process, so the debris could stop and deposit at 25 degrees. The Xinbei Mid-school was destroyed and about 500 students and teachers were

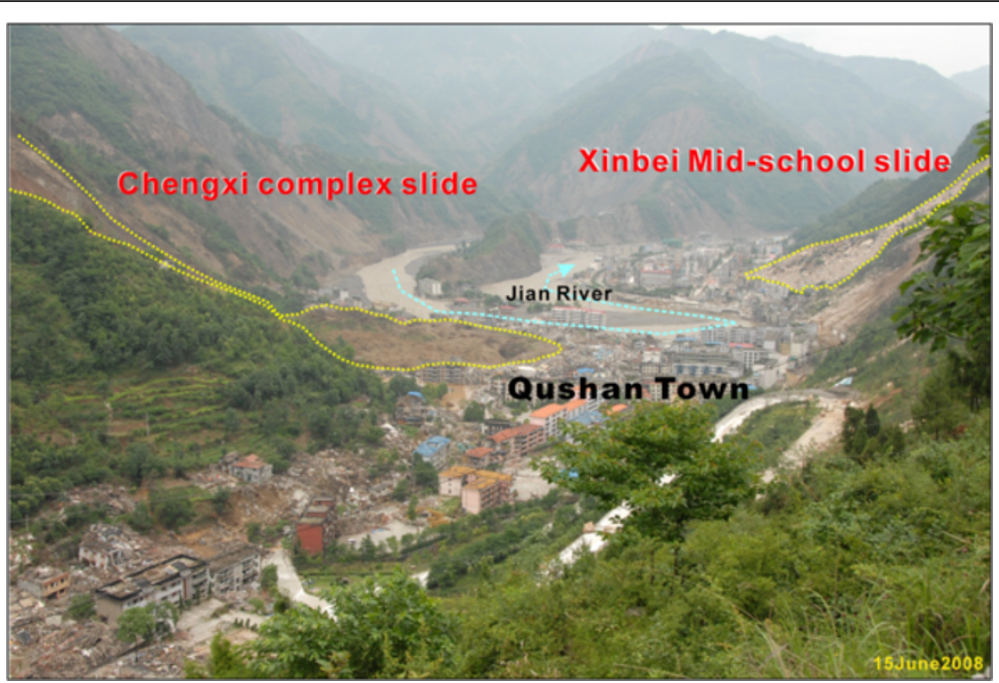

Figure 4 The Chengxi complex landslide (left) and the Xinbei Mid-school rockslide (right) in Qushan Town, Beichuan County. The Chengxi landslide killed 1,600 people and the Xinbei Mid-school rockslide killed 500 people. The dotted lines show the travel path and the extent of each landslide. 
killed, because the school was located near the foot of the slope, and in the direct path of the landslide. Additionally, the school was in very close proximity to the earthquake fault rupture, and most likely experienced a damaging level of shaking from the earthquake.

\section{A complex landslide in Donghekou Village}

A large-scale rockslide occurred on the mountain behind Donghekou Village. Movement was triggered by the earthquake, and the initial rockslide became a debris flow as it moved down the mountain. Figure $5 \mathrm{a}$ and Figure $5 \mathrm{~b}$ are an areal photo and topographic map of the Donghekou complex slide. Donghekou Village was located at the convergence of the Hongshi River and the Xiasi River. The debris flow dammed the Xiasi River and its tributary Hongshi River, and formed two landslide lakes. Part of the displaced slide mass entered the Xiasi River and flowed down the stream as a debris flow. In the source area, the average length is about $1 \mathrm{~km}$, the average width is about
$920 \mathrm{~m}$, and the total length of the rockslide and debris flow reached about $3 \mathrm{~km}$.

From Figure 6a, it can be seen that many houses were built along the Hongshi River. There were about 1,500 people living in this village. At this location, the Hongshi River formed a fan with alluvial and flood deposits. At the two sides of the Hongshi River near the converging point, the ground level is less than $1 \mathrm{~m}$ above the water level in the river. Connecting to the water level in the Hongshi River, the groundwater table in the alluvial and flood deposit is estimated to be very shallow, and the valley deposits in fully saturated conditions.

As can be seen from Figure 6b, the landslide destroyed all of the houses in this area, and dammed the rivers. Four sub-villages and an elementary school were destroyed, and about 700 people were killed. The landslide dam in the main stream of the Xiasi River is not very thick. Because of the long travel distance, the debris flow deposits spread wide and thin.
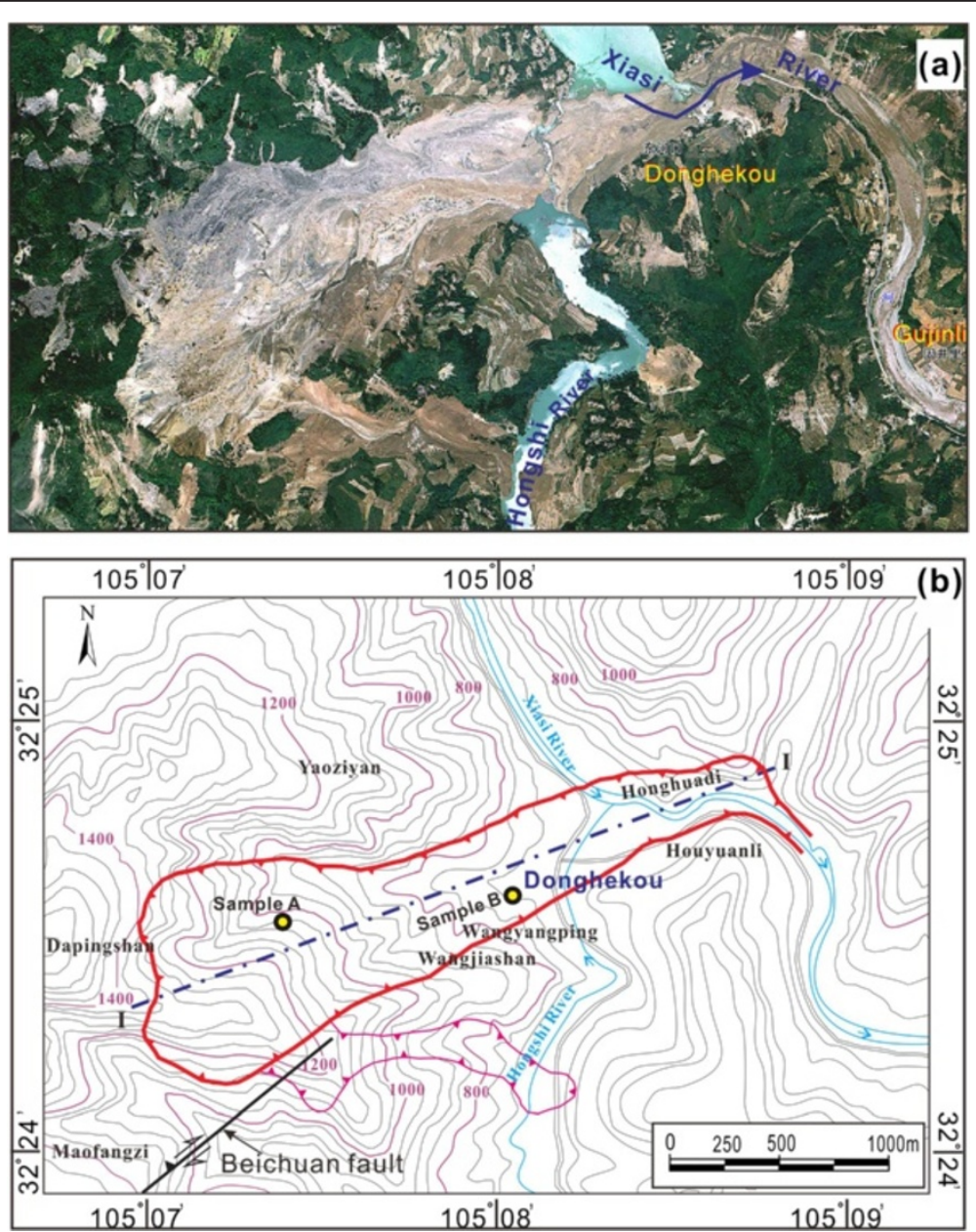

Figure 5 Areal photo and map of the Donghekou complex slide. (a) Areal photo (from Yin et al. 2009) and (b) topographic map (landslide boundaries are outlined in red). 


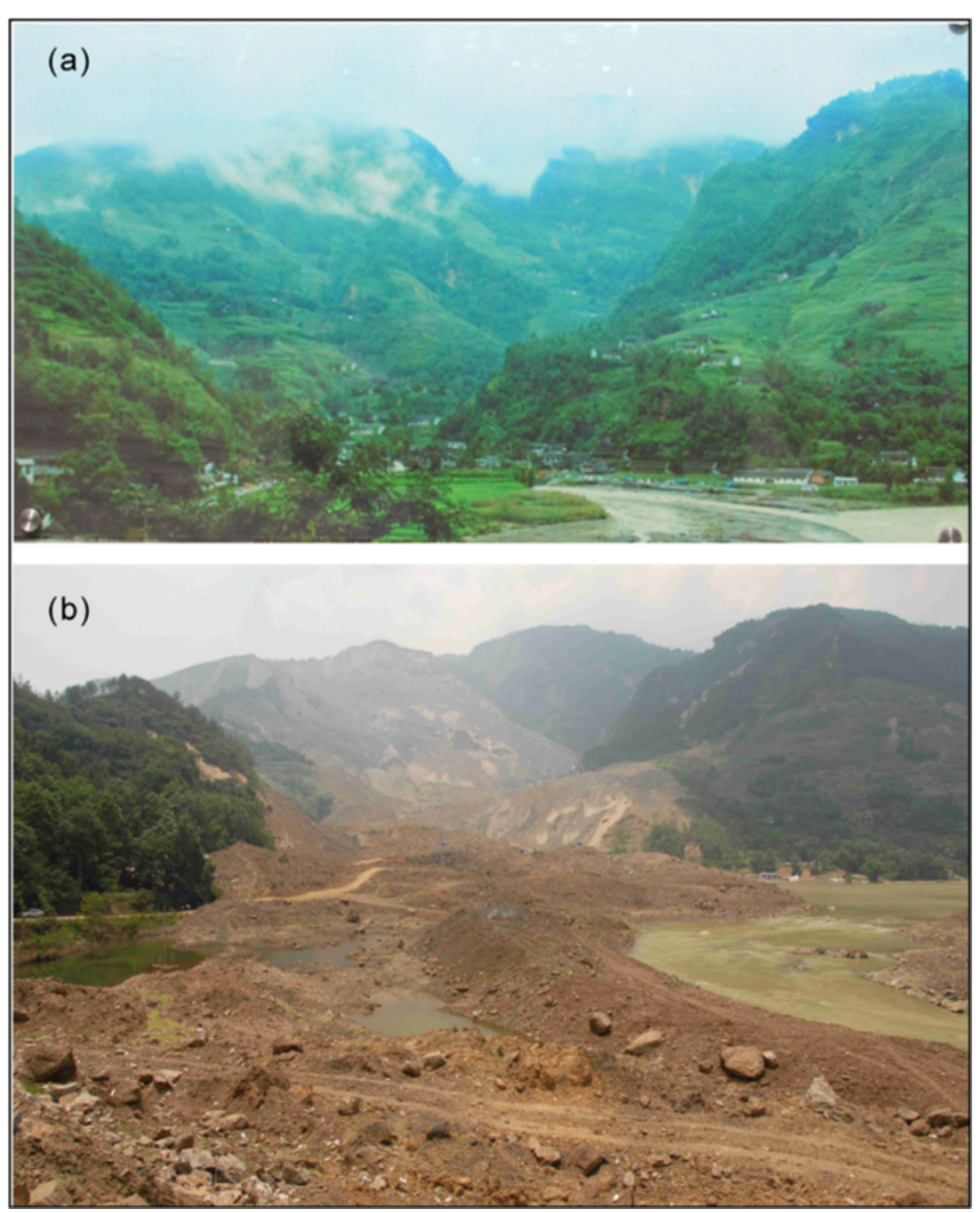

Figure 6 A complex slide (rockslide-debris flow) occurred in Donghekou Village, Qingchuan County during the Wenchuan Earthquake. (a) Photo of the region before the earthquake, taken by the local people and (b) Photo 2 months (July 2008) after the earthquake by the first author. The flow-path was considered to be fully saturated.

The slickenside faces on the mountain at the source of the landslide and the adjacent mountain, which also experienced the rockslide motion, indicate intense energy and high velocity of movement of the sliding mass. Local eyewitness said three buses full of local travelers were buried by the rapidly-moving debris because the buses had no time to escape. The flat deposits of the complex slide showed characteristic of a flowslide. There are almost no large blocks in the travel path, showing the highly fractured property of the sliding mass before it formed the landslide.

Figure 7 shows the geological components of the Donghekou rockslide-debris flow and the surrounding area. The source area of the rockslide is located in dolomitic limestone and sericitic limestone of the Yuanji formation of the Sinian period (Pre-Cambrian Era). The strata dipped to the Northwest with an average dip angle of 10 degrees. The dip direction is about 90 degrees to the sliding direction of the landslide. Within the travel path, the displaced sliding mass moved in weathered tuff sandstone, phyllite and carbon-siliceous slate of Cambrian period. These materials have a high potential for grain crushing when sheared and a relatively low permeability. According to Yuan et al. (2010), the position of a rupture of the Beichuan active fault was added in Figure 7.

Figure 8 shows the central longitudinal section (section 1-1 in Figure $5 \mathrm{~b}$ ) of the Donghekou complex slide. The average thickness of the slide mass in the source area is about $75 \mathrm{~m}$, with the maximum thickness of $110 \mathrm{~m}$, and the total volume of the Donghekou rockslide is about 69 million $\mathrm{m}^{3}$. In Figure 8, by connecting the top point of the rockslide and the toe of the debris flow, the apparent friction angle of the rockslide-debris flow was determined to be 11 degrees. This indicates a high mobility for the rockslide-debris flow. In the source area, there was much slide debris that remained, covering the sliding surface of the landslide, making it difficult to determine the material in the slide zone. Observation of the slide mass distributed 


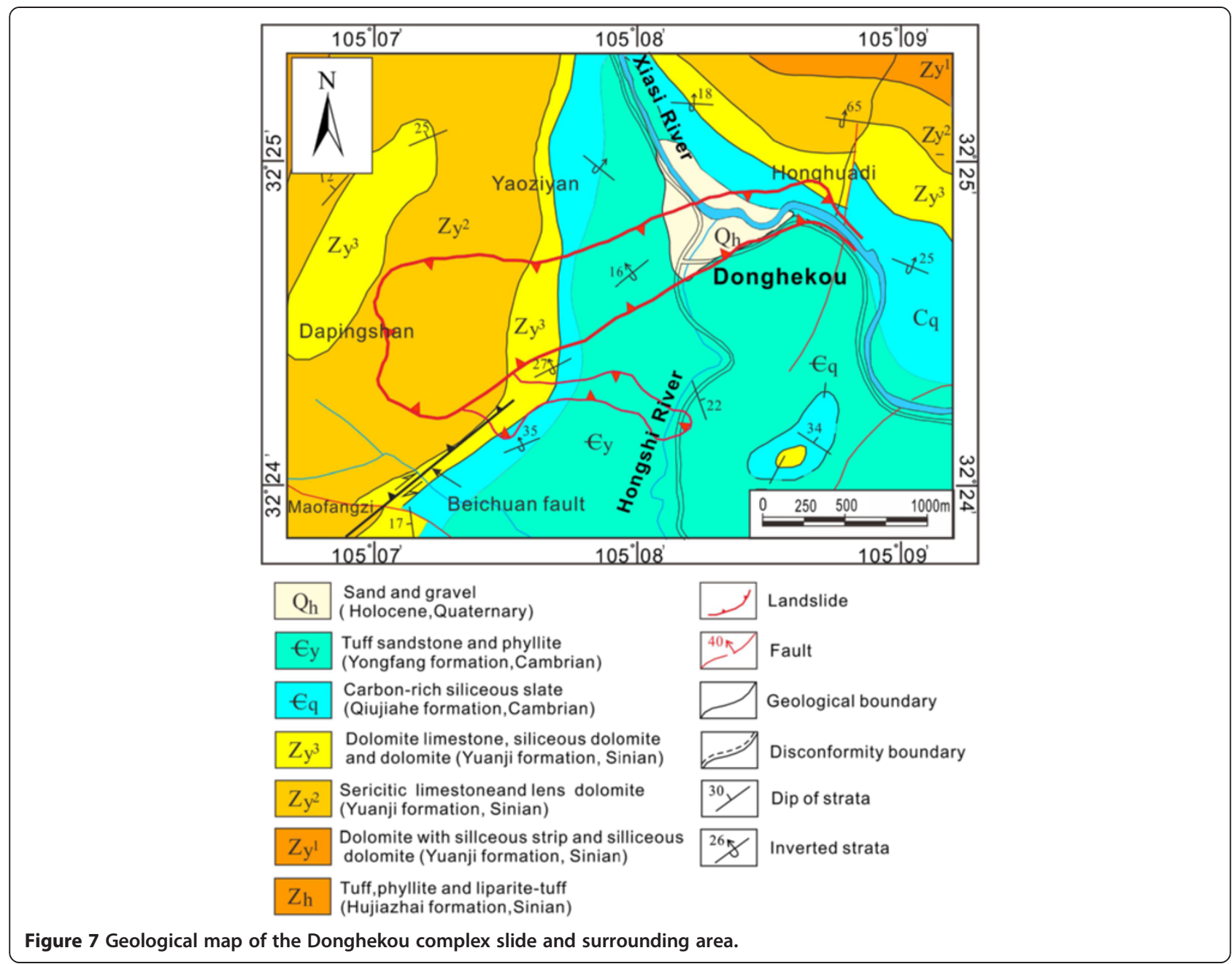

in the lower part (traveling path and deposit area), it is indicated that the sliding zone existed in the carbonsiliceous slate of the Qiujiahe formation of the Cambrian period. The structure of the slide mass during the earthquake consisted of two layers, i.e., fragmented limestone of the Sinian period overlaying weathered carbon-rich siliceous slate of the Cambrian period. In the investigation conducted in July 2008, it was observed that the weathered slate was in a soft-plastic state and fully saturated in a natural slope near the Donghekou slide.

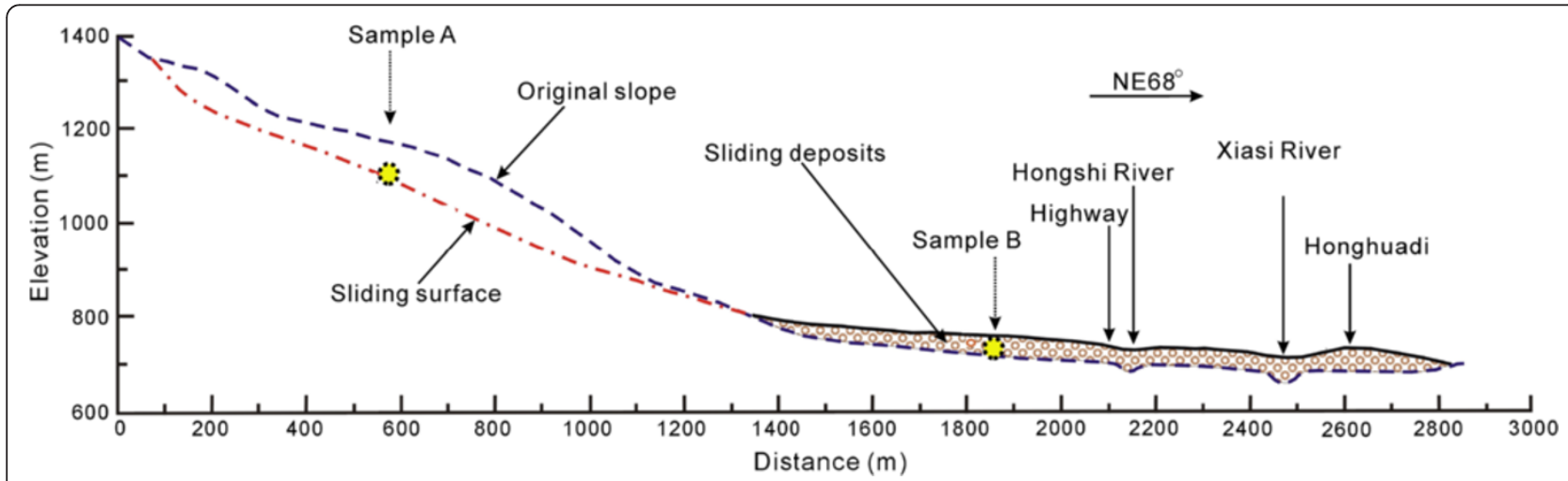

Figure 8 Longitudinal section (Section I-I in Figure 5b) of the Donghekou complex slide showing landslide topographical characteristics, and locations from which samples A and B were taken. 
For the field investigation on Donghekou slide conducted in February 2009, sampling from the source area (sample A) and valley deposit (sample B) was carried out. At the source area (Figure 9), weathered carbon-siliceous slate was labeled as sample A. Although the debris around the mountain was dry, a small amount of water was flowing down the valley. Lineaments representing shearing, indicated by the layered structure of slate with an intrusion of soft yellow clay were observed at the sampling point. Considering the size limitation of the ring shear apparatus, during sampling, boulders and gravels were sieved out, and only the grains smaller than $4.75 \mathrm{~mm}$ were collected, as a disturbed sample A. This kind of treatment in sampling may affect the peak value of shear resistance, while have no effect on the residual shear strength or that in steady state (Sassa et al. 2004), which is an important parameter for rapid and long runout slides. An old valley deposit was found beneath the displaced debris that moved in this event, and it became sample B, which was taken (Figure 10), by the same method as sample A.

Simulation tests for the initiation and motion mechanism of the Donghekou complex slide for use as a case study

We selected Donghekou complex slide as a prototype model for laboratory tests to study the initiation and

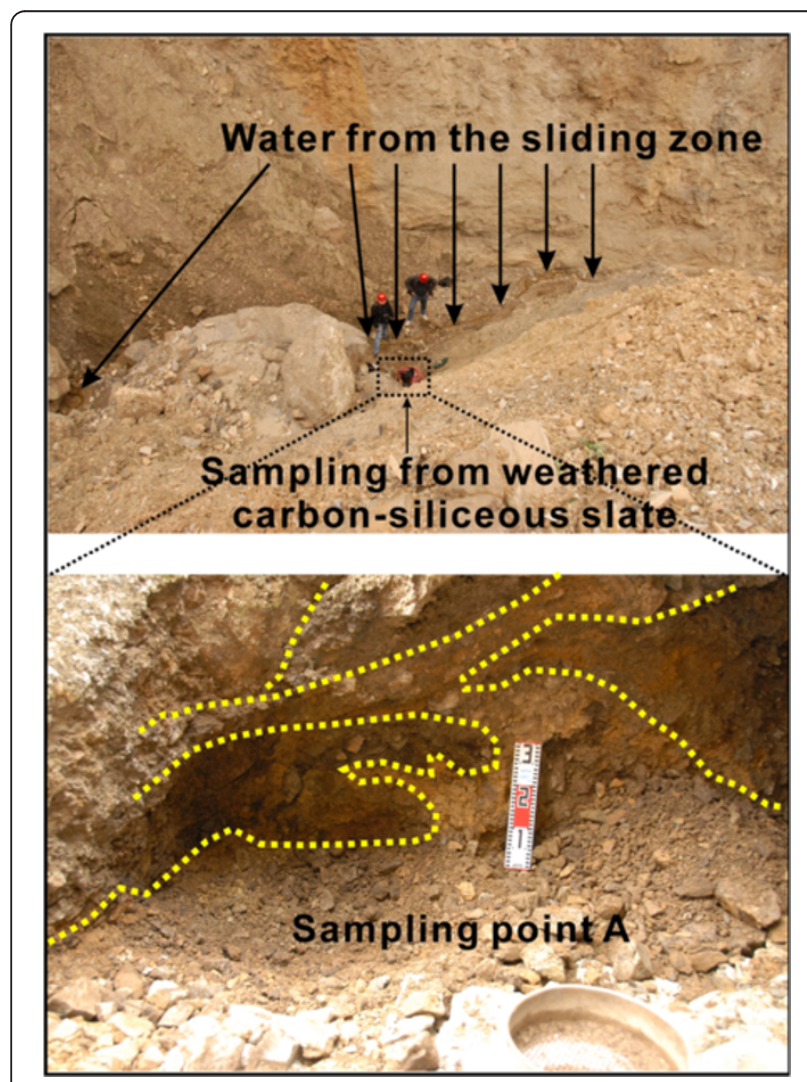

Figure 9 Location of sample A in a gully in the source area of the Donghekou complex slide.

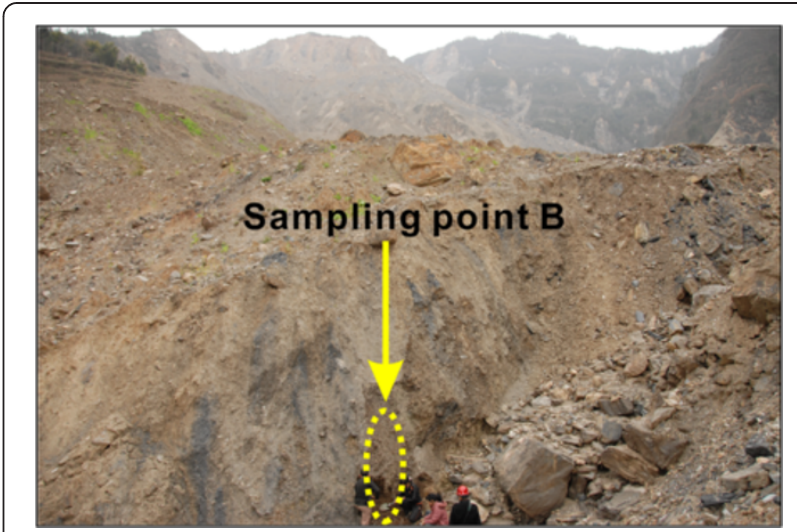

Figure 10 Location of sample B in the old valley deposit beneath the displaced sliding debris from the landslide.

motion mechanisms of landslides triggered by the Wenchuan earthquake, because the Donghekou complex slide moved for a long distance and showed a high rate of speed. Long travel distance implies a very low shear resistance during the landsliding. We try to find the mechanism to make the low shear resistance possible during the landslide motion. After the earthquake, many analyses and discussions have been conducted for this landslide, and the most comprehensive comments were given by Qi et al. (2011). They mentioned that besides the influence of the earthquake, the high relief and steep inclination in the source slope and plentiful saturated loose deposits formed by a river or gully in the travel path had a great contribution to the rapid and long runout landslides. In this paper, we explain the initiation and motion mechanisms using the concept of undrained shearing, although other mechanisms may also exist.

Using the undrained ring shear apparatus developed at Kyoto University, Japan (Sassa 1997; Sassa et al. 2004), two types of simulation tests were conducted. They are: (a) Simulation test to clarify the initiation mechanism of the Donghekou complex slide triggered by the Wenchuan earthquake and (b) Test to simulate the movement when the failed sliding mass loaded onto the valley deposits, and clarify the motion mechanism for long runout and in high speeds.

\section{The geotechnical simulation test for the Donghekou slide with the actual seismic motion}

In a geotechnical simulation test, the initial stress level, i.e., the initial normal stress, shear stress, and pore-water pressure existing in the slope before earthquake should be reproduced first to simulate the initial stress condition in the slope, and then the cyclic loading caused by a seismic motion can be applied to observe the effect on the slope caused by the earthquake. Because the Donghekou complex slide is so large and the earthquake 
was so strong, it is impossible to simulate both the initial stress condition of the slope and the cyclic loading from the earthquake at the same time. As commonly understood in slope stability evaluations, the slope angle is much more important than the thickness of sliding mass. That is, the relationship between the initial normal stress and shear stress is more important than the absolute value of the normal stress and shear stress. In this test, with consideration of the stress capacity of the ring shear apparatus, the initial slope angle of the Donghekou complex slide was maintained, while the thickness of the sliding mass was reduced significantly.

For the initial stress condition of the Donghekou rockslide, the slope angle of 25 degrees was used at the source area. The initial normal stress and shear stress were obtained from the slope angle, thickness of the sliding mass, and the unit weight of the soil/rock. With the consideration of the capacity of the apparatus, a thickness of $20 \mathrm{~m}$ was used to replace the actual average thickness of $75 \mathrm{~m}$. The unit weight of the sliding mass was assumed to be $18 \mathrm{kN} / \mathrm{m}^{3}$. Statistically, under the same slope condition, larger scale landslides always show a higher mobility (Okuda 1984). Theoretically, for an infinite long slope consisting of non-cohesive soils, the slope stability has no relationship with gravitational acceleration. Considering that the stress level in the simulation test is about $27 \%$ of the actual, the initiation mechanism and motion mechanism of the Donghekou complex slide can be qualitatively interpreted. The actual failure should have a higher mobility than that shown in the laboratory test.

According to Wang et al. (2010) and Lu et al. (2010), there are three strong motion stations, i.e., Wolong, SFB, and MZQ, located around the Longmen Shan fault system. The SFB station experienced a similar seismic intensity as that of the Donghekou complex slide. According to a detailed analysis by Li et al. (2008), the Donghekou slide and the SFB station are located in the same seismic intensity zone of level-VIII in the Chinese Seismic Intensity Scale. For this reason, the SFB record was used in the geosimulation test on Donghekou slide. The SFB strong motion station was located about $1.2 \mathrm{~km}$ from the secondary fault rupture and it recorded a large vertical motion in Bajiao Town, Shifang County (Lu et al. 2010). According to Kurahashi and Irikura (2010) and Wang et al. (2010), the SFB monitoring station is near an asperity and in the forward rupture direction. The site is primarily alluvium, and the observation point is on ground (free field station). The seismometer was set $20 \mathrm{~m}$ below the ground surface. During the earthquake, the SFB station recorded three seismic wave components (EW and NS in the horizontal plane, and UD in the vertical plane) (Figure 11). The PGAs (peak ground acceleration) at EW, NS, and vertical directions are 557.2 gal, 633.7 gal, and 581.9 gal, respectively.

Generally, seismic intensity is attenuated by distance, and amplified by standing elevation and loose deposits.
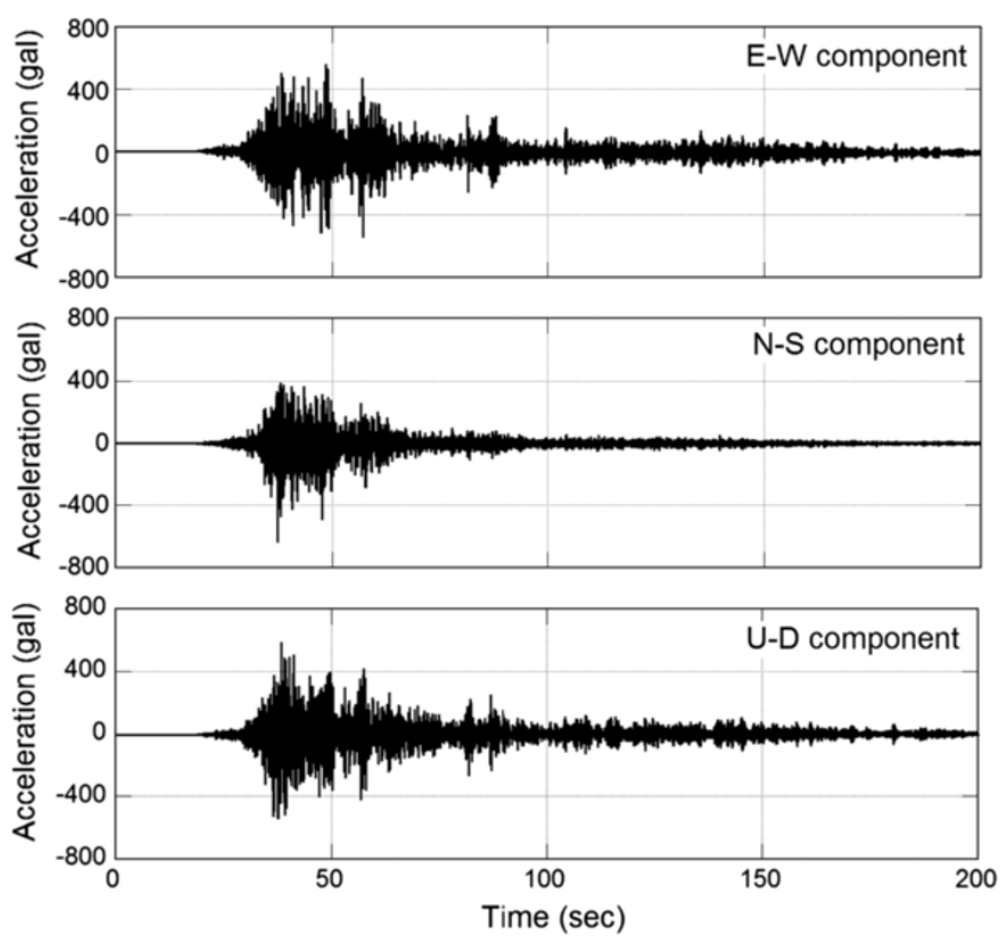

Figure 11 Three components (EW, NS, and UD) of the Wenchuan earthquake recorded at SFB strong-motion station. 
(a)

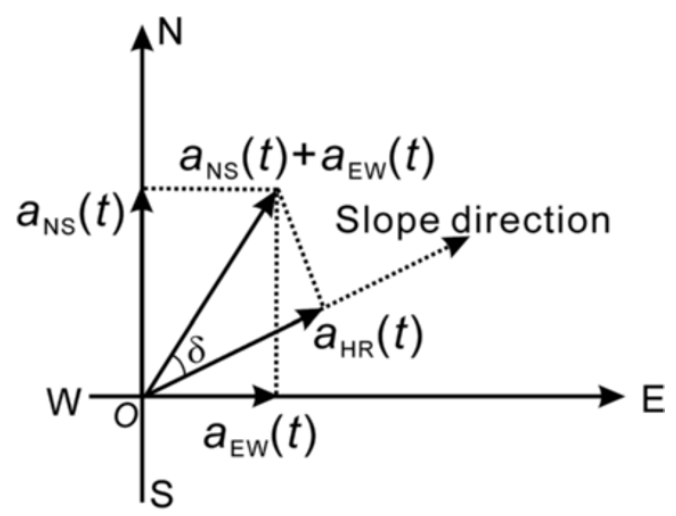

(b)

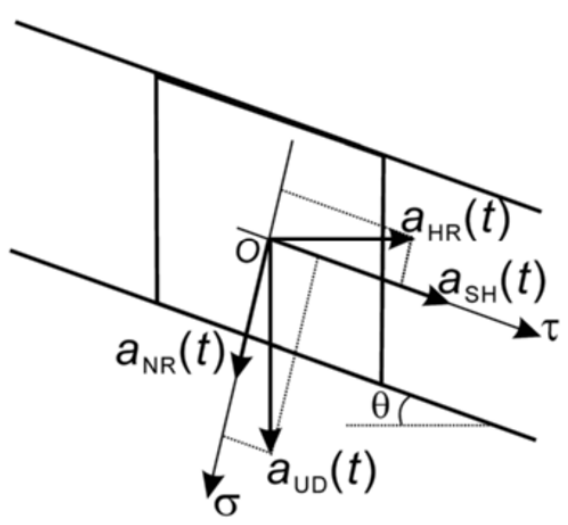

(c)

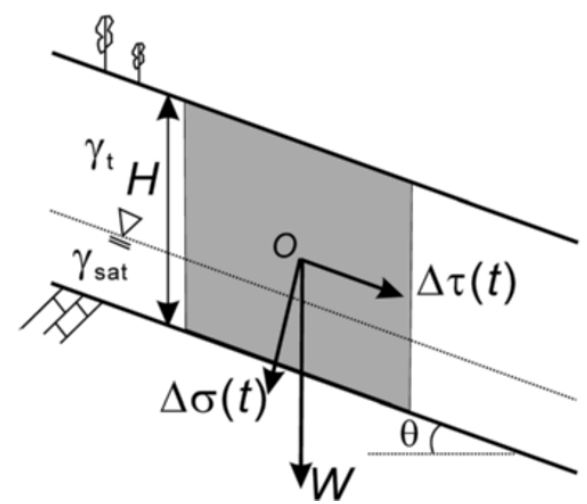

Figure 12 The synthesizing process using the three components of the seismic wave to calculate the normal stress increment and shear stress increment acting on the sliding surface. (a) Transfer of the horizontal (EW and NS) acceleration components $\left(a_{E W}(t)\right.$ and $\left.a_{N S}(t)\right)$ to slope direction in horizontal plane $\left(a_{H R}(t)\right) ;(b)$ Transfer of the horizontal acceleration component $\left(a_{H R}(t)\right)$ along the slope direction and the vertical acceleration component (UD) (aUD (t)) to normal stress component $\left(a_{N R}(t)\right)$ and shear stress component ( $\left.\mathrm{a}_{\mathrm{SH}}(\mathrm{t})\right)$ acting on the sliding surface; (c) Obtaining the initial normal stress and shear stress $\left(\sigma_{0}, \tau_{0}\right)$, and the increments of normal stress and shear stress acting $(\Delta \sigma(\mathrm{t}), \Delta \tau(\mathrm{t}))$ on the sliding surface by multiplying acceleration and mass of the soil column. $\delta$ is the angle between slope direction and the horizontal shaking direction of the earthquake; $\theta$ is the slope angle; $\gamma_{\text {sat }}$ is unit weight of the saturated soil layer, and $\gamma_{t}$ is unit weight of the soil over the groundwater table; $H$ is the depth of sliding mass.
To apply the seismic record to Donghekou slide, modifications would have to be made. However, when considering the following factors, we assumed the seismic intensity at the Donghekou slide can be treated as the same as that recorded in SFB station. They are: 1) the SFB station is on the hanging wall of the secondary fault, and Beichuan fault is located near the source area of the Donghekou complex slide (Yuan et al. 2010); and 2) the elevation difference between source area and toe of Donghekou slide is about $700 \mathrm{~m}$. The source area of the Donghekou slide should have been affected by the seismic amplification. The SFB station is located in alluvium, so the recorded waves also should have been amplified. As both sites are located in the same seismic intensity zone of VIII, and the amplification by standing elevation in the Donghekou complex slide and the alluvium deposit at the SFB station can be treated as equivalent qualitatively. Although we know that the geological and topographic conditions and the distance to the source fault of the earthquake may cause amplification and attenuation of the seismic shaking in different site, the coefficient of the amplification and attenuation is very difficult to be determined. So for simplification, the seismic wave monitored at SFB station was used to form the seismic loading input signal for the simulation test, without any amplification and attenuation (Wang et al. 2000).

Through directional transformation shown in Figure 12 with consideration of the initial slope condition of the Donghekou rockslide (slope angle and initial thickness), the earthquake induced incremental normal stress and the shear stress component acting on the sliding surface of the Donghekou rockslide could be calculated.

The seismic wave direction transformation procedure is presented below:

(1) Determination of the horizontal seismic acceleration $\mathrm{a}_{\mathrm{HR}}(\mathrm{t})$ in the sliding direction of the landslide by means of the NS component $\mathrm{a}_{\mathrm{NS}}(\mathrm{t})$ and the EW component $\mathrm{a}_{\mathrm{EW}}(\mathrm{t})$ of the earthquake (Figure 12a), using Equation (1).

$$
\mathrm{a}_{\mathrm{HR}}(\mathrm{t})=\sqrt{\mathrm{a}_{\mathrm{NS}}^{2}(\mathrm{t})+\mathrm{a}_{\mathrm{EW}}^{2}(\mathrm{t})} \cos \delta
$$

(2) Determination of the two components in parallel direction and normal direction to the sliding surface, by summing the horizontal component $\mathrm{a}_{\mathrm{HR}}(\mathrm{t})$ and the vertical component $\mathrm{a}_{U D}(\mathrm{t})$ (Figure 12b). The component in the normal direction to the sliding surface $a_{N R}(t)$, and the component in the shear direction of the sliding surface, $a_{S H}(t)$, are obtained as shown in Equations (2) and (3). Where, $\theta$ is the slope angle of the landslide.

$$
\mathrm{a}_{\mathrm{NR}}(\mathrm{t})=\mathrm{a}_{\mathrm{UD}}(\mathrm{t}) \cos \theta-\mathrm{a}_{\mathrm{HR}}(\mathrm{t}) \sin \theta
$$




$$
\mathrm{a}_{\mathrm{SH}}(\mathrm{t})=\mathrm{a}_{\mathrm{UD}}(\mathrm{t}) \sin \theta+\mathrm{a}_{\mathrm{HR}}(\mathrm{t}) \cos \theta
$$

(3) Calculation of the initial stress and the seismic stress increment on the sliding surface. A soil column with a unit width along the slope was considered as shown in Figure 12c. So, the weight of a unit column is given by Equations (4) and (5).

$$
\begin{aligned}
& \mathrm{W}=\gamma \mathrm{H} \cos \theta \\
& \mathrm{m}=\mathrm{W} / \mathrm{g}
\end{aligned}
$$

The initial stress condition can be determined using Equations (6) and (7).

$$
\begin{aligned}
& \sigma_{0}=\mathrm{W} \cos \theta \\
& \mathrm{\tau}_{0}=\mathrm{W} \sin \theta
\end{aligned}
$$

Moreover, the seismic stress increment can be determined from Equations (8) and (9).

$$
\begin{aligned}
& \Delta \sigma(\mathrm{t})=\operatorname{ma}_{N R}(\mathrm{t}) \\
& \Delta \mathrm{\tau}(\mathrm{t})=\operatorname{masH}_{\mathrm{SH}}(\mathrm{t})
\end{aligned}
$$

The initial normal stress is $295.7 \mathrm{kPa}$ and the initial shear stress is $137.9 \mathrm{kPa}$ at the source area of the Donghekou rockslide. These stress values were calculated based on a 25 degree average slope and a sliding mass thickness of $20 \mathrm{~m}$ with a unit weight of $18 \mathrm{kN} / \mathrm{m}^{3}$. Figure 13 shows the synthesized input wave of normal stress and shear stress for the Donghekou slide. The initial stress condition of the initial slope before the earthquake, and the stress increment caused by the earthquake are also included. Because the earthquake occurred during a typical rainy season, the static pore-water pressure acting on the potential sliding surface was ignored, but the sliding surface itself was estimated to be in a fully saturated condition.

The test was conducted with disturbed sample A from the source area. The sample was dried in an oven at $105^{\circ} \mathrm{Cat}$ first, and then separated into grains by gently applying a wooden hammer. By means of free fall deposition method (Ishihara 1993), the dry sample grains were set in the shear box, and saturated by carbon dioxide gas and de-aired water. The saturation degree was confirmed by the $B_{\mathrm{D}}$ value suggested by Sassa (1988). When the $B_{\mathrm{D}}$ value is higher than 0.95 , the sample is recognized as fully saturated. In this test, $B_{\mathrm{D}}$ was 0.97 , showing a fully saturated condition. After normal consolidation at 295.7 $\mathrm{kPa}$, the initial shear stress $137.9 \mathrm{kPa}$ was loaded gradually while keeping the sample in a drained condition to avoid excess pore-water pressure generation. At this moment, the void ratio of the soil sample reached 0.650 . Then, the sample was changed to an undrained condition, and the input signals of seismic loading (Figure 13) were loaded to simulate the condition of the original slope when the earthquake motion was applied as the initiation factor.

Figure 14 shows the entire data series for the geosimulation test on the Donghekou rockslide. A large decrease of the shear resistance and a rapid generation of the excess pore-water pressure with the application of

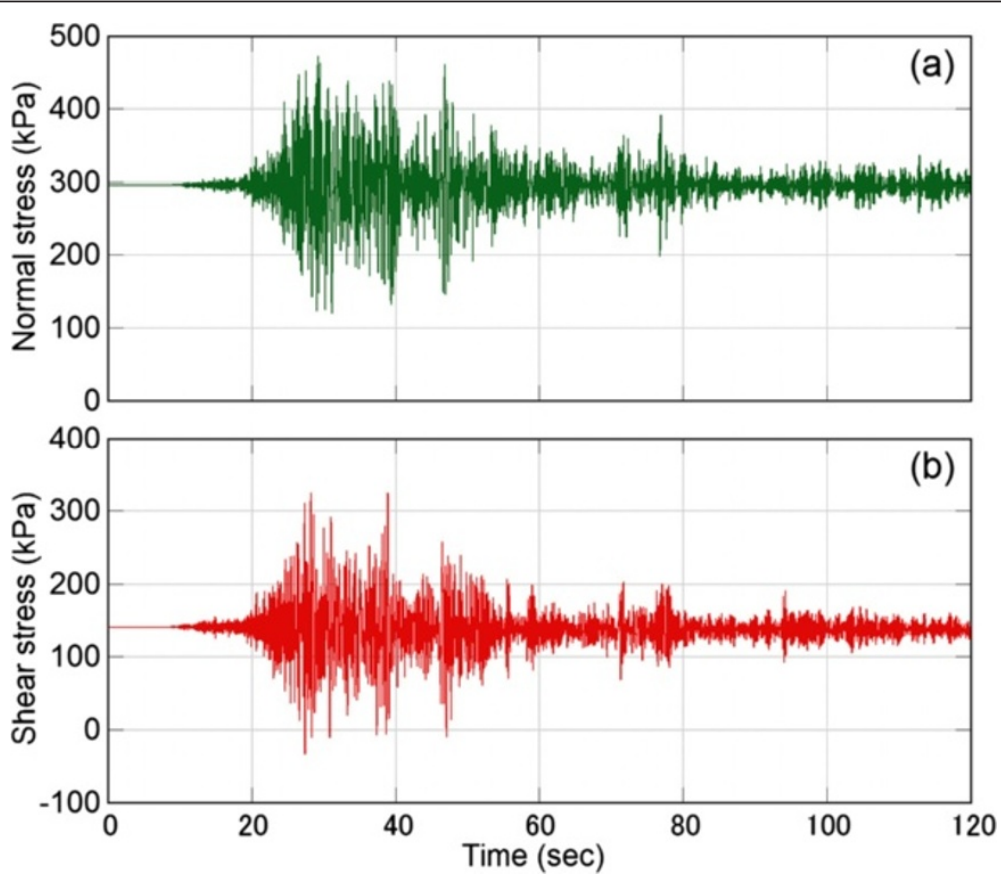

Figure 13 Synthesized input signal for stresses due to seismic loading for the simulation test on the Donghekou landslide to show the initiation mechanism of the landslide triggered by the earthquake. (a) normal stress and (b) shear stress. 

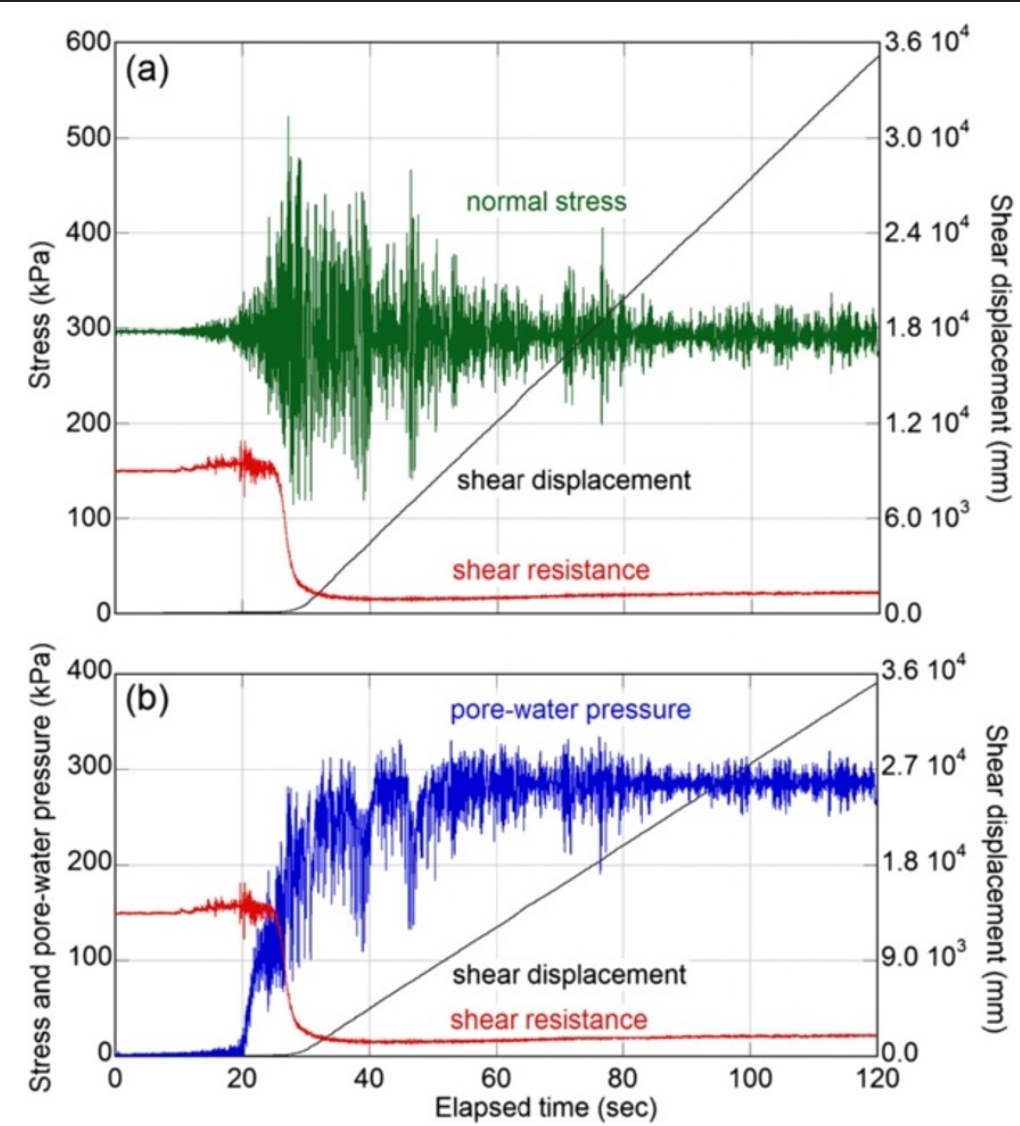

Figure 14 Geo-simulation test results for the Donghekou rockslide using the actual seismic wave components as the triggering process. (a) normal stress, shear resistance and shear displacement (b) pore-water pressure, shear resistance and shear displacement.

the normal stress was observed. Figure 15 shows a closeup of the first interval of strong shaking, from 18 to 30 seconds. From the two figures, it can be seen that the sample failed at about 10 seconds from the beginning of the earthquake, and the shear displacement accelerated at about 25 seconds. At the same time (from 20 seconds),

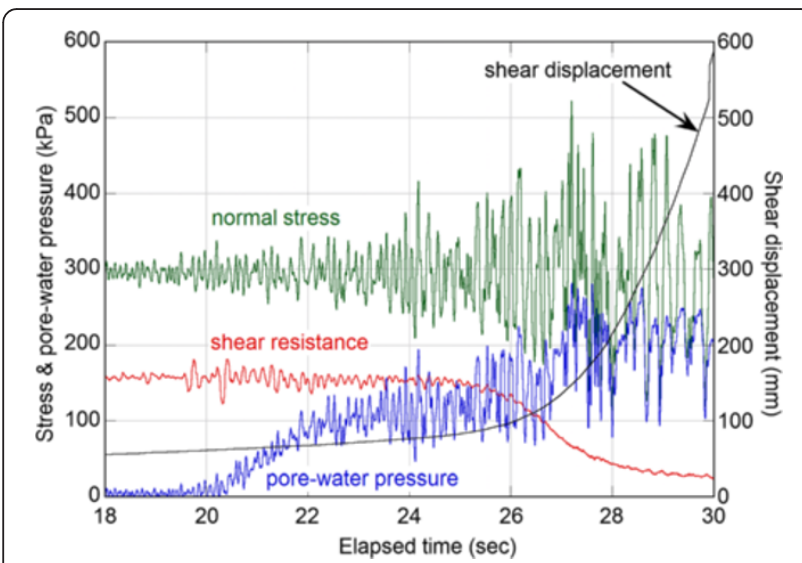

Figure 15 Close-up of part (18-30 sec) of the geo-simulation test results for the Donghekou rockslide. the pore-water pressure shows a rapid increase, and reached the same value as the normal stress at about 45 seconds, reaching the point of full liquefaction. Corresponding to the rapid increase of the pore-water pressure, the shear resistance decreased rapidly, and reached a very low value of about $15 \mathrm{kPa}$. At the end of the seismic loading, the shear displacement reached about $35 \mathrm{~m}$ with a high speed of $0.38 \mathrm{~m} / \mathrm{sec}$ (the maximum speed of the apparatus at the selected gear).

In the field of liquefaction study, a loose structure of saturated sand layer is important for liquefaction when triggered by an earthquake. However, for a dense sandy soil layer, since the excess pore-water pressure related to the structure is limited or negative, a contribution from grain crushing is expected. Under undrained conditions, when a dense sandy soil layer is sheared, grain crushing will create a tendency for volume shrinkage, and result in an increase of excess pore-water pressure. Sassa et al. (2004) called this phenomenon "sliding surface liquefaction". Although it is recognized as a reasonable explanation for landslides with high mobility in dense sandy soil slopes, the evidence of grain crushing is limited in related case studies on rapid and long runout landslides. 


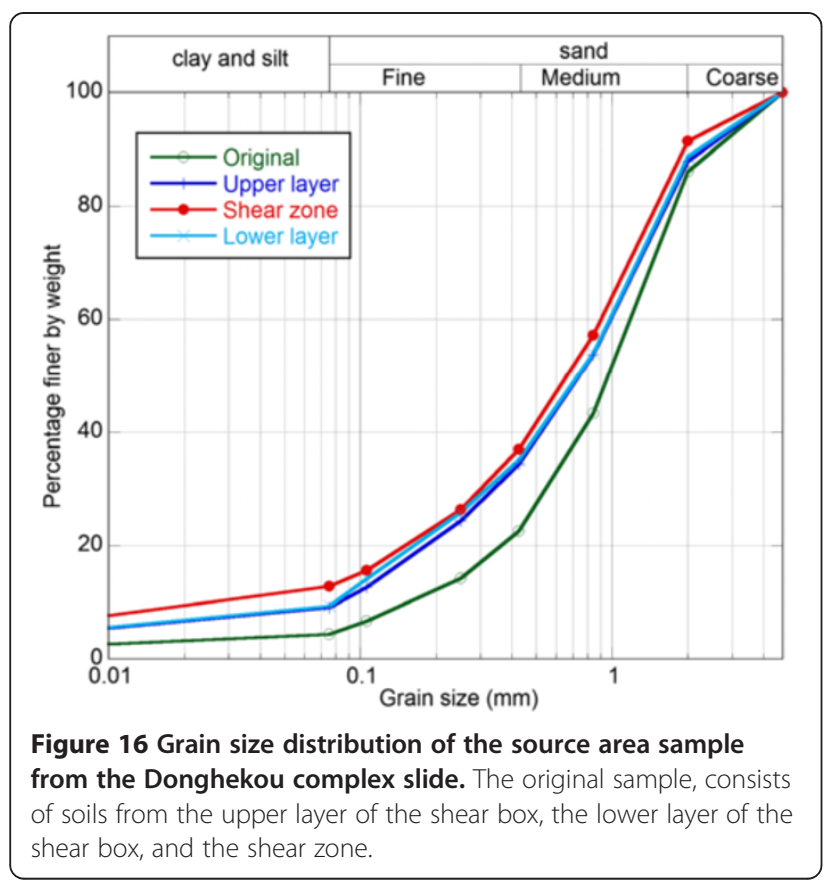

So, in this test, after the undrained shearing to $35 \mathrm{~m}$ was completed, the sample in the shear box was taken out, and the grain size distributions were analyzed (Figure 16). When compared with the original sample, it is evident that grain crushing occurred throughout the whole material of the samples. However, the material in the shear zone was finer than the upper and lower zones. Although migration of particles in the shear box can make the value slightly different from the reality, it is the small particles that were transported from the shear zone to the upper and lower sides because of high water pore-pressure at the shear zone (Sassa et al. 2004). It is evident that grain crushing can occur under undrained conditions, and it may contribute to the "sliding surface liquefaction" of the soil during shearing.

\section{Results of the simulation test showing the impact of failed slide mass loading into the valley deposit}

To simulate the process of a debris flow triggered by a rockslide, the model proposed by Sassa et al. (1997) was applied (Figure 17). The slide mass moved down the slope (I), and applied load onto the valley deposits at the foot of the slope (II). When a surface-water stream or subsurface flow existed and some of the deposits were saturated, the valley deposit was sheared under undrained loading and transported downstream together with the sliding mass (III) (Sassa et al. 2004). In this study, we change the saturated condition of valley deposits to three patterns - dry, partially saturated, and fully saturated - to observe the significance of the hydrogeological conditions along the travel path. A column of unit width, which is a part of the valley deposit, was considered. In the position (I) of the sliding mass, the weight of the column $\left(W_{0}\right)$ was in effect. When the sliding mass moved onto the valley deposit (II) with a certain velocity, it provided dynamic

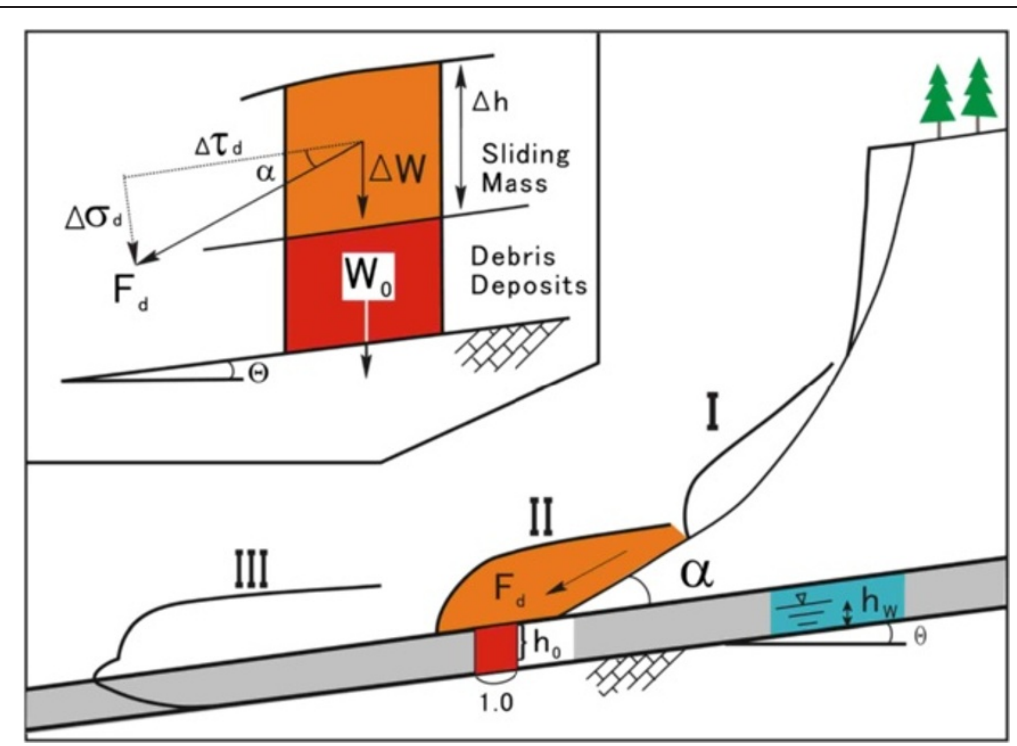

Figure 17 Model of the landslide triggered by a debris flow (Sassa et al. 1997). The process can be divided into three stages. At stage I, the displaced sliding mass slid in the source area of the landslide. At stage II, the displaced sliding mass quickly moved onto a deposit layer (with a slope angle of $\theta$ ) in front of the landslide at an angle of $a . F_{d}$ is the impact force from the displaced sliding mass on the deposit layer. $h_{O}$ is the depth of the new sliding surface in the deposit layer, $h_{w}$ is the height of groundwater table over the new sliding surface. At stage III, the impact force disappeared, and the displaced sliding mass moved together with the deposit layer. The upper left corner is a close-up of a column in stage II. 
loading on the column. Here, it is assumed that the applied stress on the valley deposits was the sum of the static stress, $W$ (load due to the weight of the sliding mass) and the dynamic (impact) stress, $F_{\mathrm{d}}$, working in the direction of motion of the sliding mass.

The input parameters were determined by considering the actual slope condition at sampling point $B$ and the capacity of the apparatus, as explained in the previous test. By using $\alpha=17^{\circ}, \theta=6^{\circ}, \mathrm{h}_{0}=5 \mathrm{~m}, \mathrm{~h}_{\mathrm{w}}=0, \Delta \mathrm{h}=15 \mathrm{~m}$, $\gamma_{\mathrm{t}}=18 \mathrm{kN} / \mathrm{m}^{3}$, and $F_{\mathrm{d}}=1$, the impact stresses (normal stress and shear stress) for sample B were formed as shown in Figure 18a. The impact forces increased to peak in 5 seconds, and disappeared in 5 seconds. After the impaction, the valley deposits flowed down the gentle slope with the sliding mass from the source area of the rockslide.

Graphs b - d shown in Figure 18 illustrate the results for the three conditions (dry, partially saturated, fully saturated). When the failed sliding mass traveled down to the valley deposits, in a dry condition, only very limited shear displacement occurred, and when the valley deposits were fully saturated, a large travel distance together with high speed motion occurred. In the fully saturated condition, a high pore-water pressure was measured, and the shear resistance became small (about $45 \mathrm{kPa}$ ). This could be a possible reason for the long runout motion of more than $2 \mathrm{~km}$ of the Donghekou complex slide. Figure 19 shows the total stress path and effective stress path of the test with the fully saturated soil sample. Started from the same point, the total stress path (TSP) moved to the right side and then dropped down to a lower level of shear resistance, which means an increase in normal stress at first and a decrease in shear resistance, while the effective stress path (ESP) moved to the right at once, then returned to the left. This path shows the process of excess pore pressure generation. The apparent friction angle (the inclination of the line connecting the end of TSP and the original point) is only 6.0 degrees. It means that a high mobility of the sliding mass when it loaded on the saturated
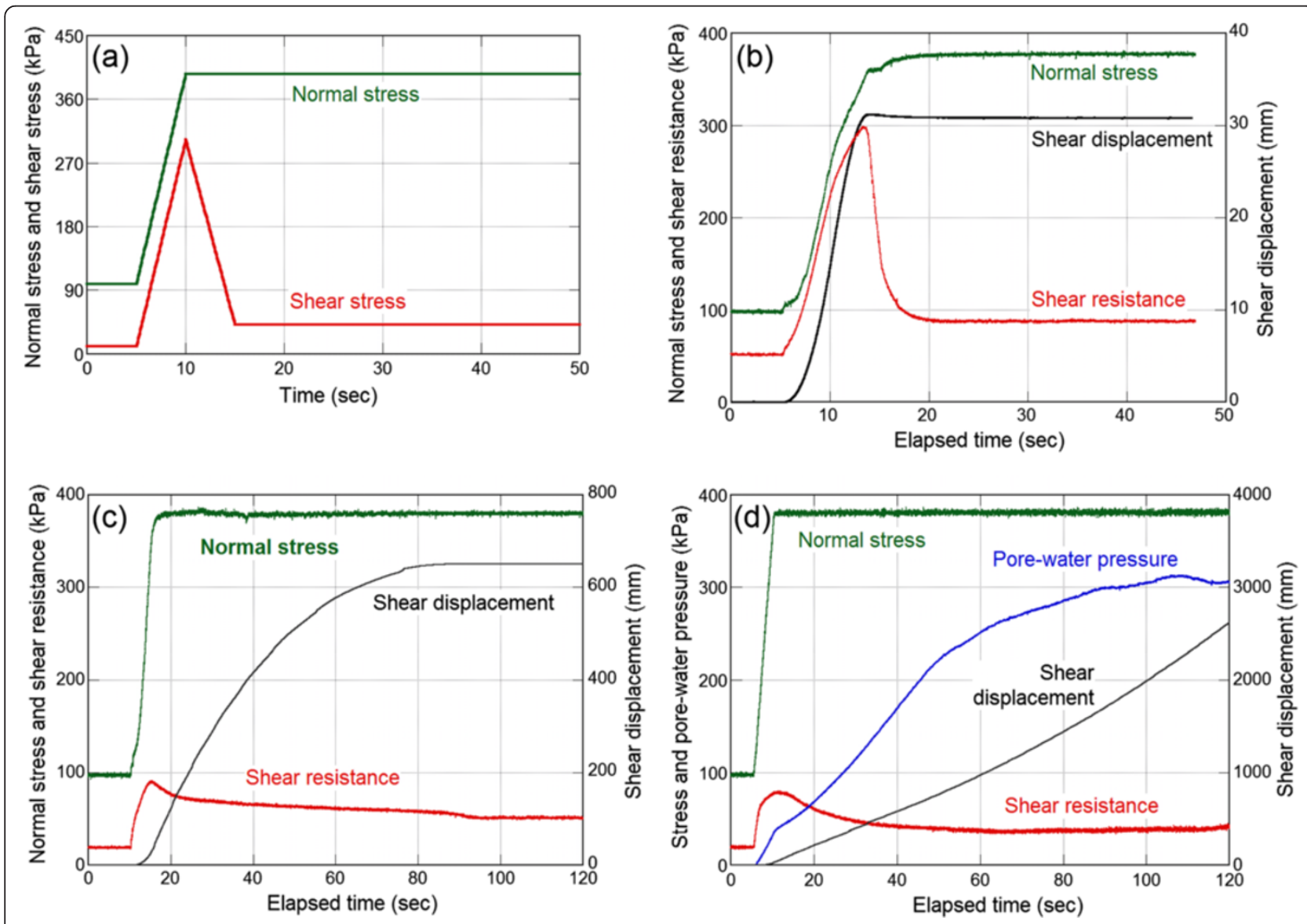

Figure 18 Loaded stress signals and results of the Donghekou complex slide motion simulation test using Sample B. Graph (a) shows loaded stress signals; Graph (b) shows results of dry condition; Graph (c) shows results of partially saturated condition; and graph (d) shows results of fully saturated condition. 


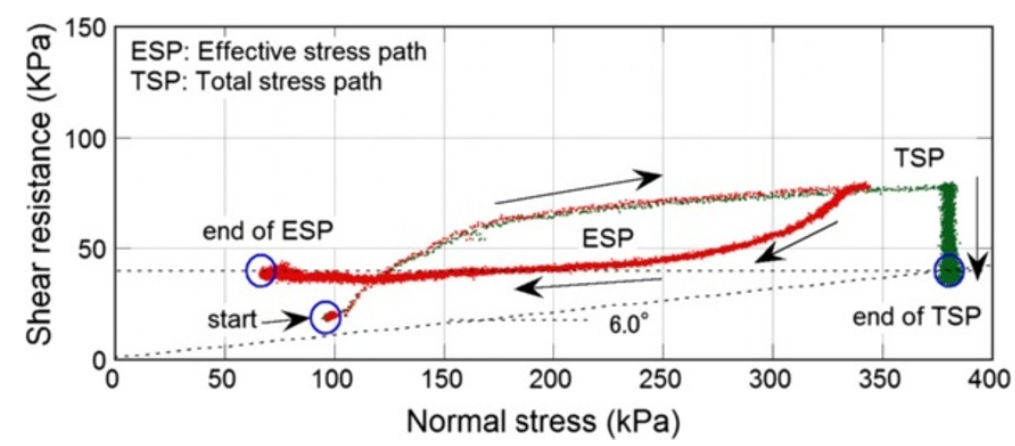

Figure 19 Total stress path (TSP) and effective stress path (ESP) of the simulation test for fully saturated sample B.

valley deposits can be expected. The small apparent friction angle will result in high velocity and long travel distance for the sliding mass.

As mentioned previously, the angle from the toe of the Donghekou complex slide and the source area is about 11 degrees. Caution is required to compare the actual apparent friction value with that obtained in ring shear tests. The most important difference is that the total normal stress in ring shear test is constant, while in the actual case, the normal stress generally decreases to lower level because the sliding mass always becomes thinner and thinner. Other reasons causing this difference may include (1) energy dissipation caused by the impact of the collision of the debris among the sliding mass, (2) some parts may not be in a fully saturated condition mobilizing a higher shear resistance. On the other hand, the test in laboratory was conducted in a simple and ideal situation with a fully saturated sample in undrained conditions. These factors may cause the difference between the actual apparent friction angle and test value. Moreover, it is clear that the test shows that the existence of the water is a very important factor for the rapid movement and long travel distance.

\section{Conclusions}

Through field investigation of the long runout landslides triggered by the Wenchuan earthquake and experimental study of the Donghekou complex landslide, in particular, it was found that the valley water and groundwater played key roles in the long runout and rapid landslide motion during the great earthquake. In reality, there is only limited information on the actual rainfall, valley water, and ground water conditions during the earthquake. It is suggested that in the source area, the landslide gained velocity when the "sliding surface liquefaction" phenomenon occurred as a result of undrained shearing in a saturated sliding zone. In turn, the displaced sliding mass can exert an impact on the valley deposit. When the valley deposit is also saturated, liquefaction can occur causing the valley deposit to work as a sliding zone with low shear resistance, transporting the sliding mass from the source area for a long distance. There may be other mechanisms for rapid and long runout landslides triggered by the earthquake, however, the hydrogeological condition in the source area and traveling path is certainly a key factor in controlling the shear resistance, and should be considered seriously in risk assessments for landslide disaster reduction. Impacts and losses depended upon whether the landslide moved but was abruptly stopped, and whether the landslides moved for a long distance with high speed. It would be useful if more earthquake-induced landslide case studies using methods outlined in this paper were to be analyzed. We could then be closer to concluding whether there are the same and/or additional variables that affect rate of movement, extent of movement and their relationships to the rates of death and damage.

\section{Competing interests}

The authors declare that they have no competing interests.

\section{Authors' contributions}

All authors participated the field investigations; FW \& QC conducted the sampling; FW \& PS conducted the ring-shear tests; FW \& LH drafted the manuscript; all authors read and approved the final manuscript.

\section{Acknowledgements}

The field investigation and sampling was partially supported by Chinese State Key Fundamental Research Program Project (2008 CB425802, representative: Peng Cui). Dr. Laizhen Pei of Institute of Mountain Hazards and Environment, Chinese Academy of Sciences guided the field investigation. Dr. Hongshuai Liu of Institute of Engineering Mechanics, China Earthquake Administration supplied the seismic record of the Wenchuan earthquake. The authors deeply appreciated the discussions with Prof. Xiyong Wu of Southwest Jiaotong University, China, Prof. Masahiro Chigira of Kyoto University, Prof. Kazuo Konagai of University of Tokyo, and Prof. Satoshi Tsuchiya of Shizuoka University, Japan in the field investigation. The field investigation and ring shear tests were conducted when the first author worked in Disaster Prevention Research Institute of Kyoto University, Japan. The authors acknowledge Dr. Janusz Wasowski of CNR-IRPI, Italy, Dr. Julian Bommer of Imperial College London, and Beena Ajmera of California State University, Fullerton, USA for their helpful and constructive comments to improve the manuscript. 


\section{Author details}

${ }^{1}$ Department of Geoscience, Shimane University, Matsue, Japan. ${ }^{2}$ Institute of Geomechanics, Chinese Academy of Geological Sciences, Beijing, China. ${ }^{3}$ National Landslide Information Center, U. S. Geological Survey, Denver, USA. ${ }^{4}$ Faculty of Geosciences and Environmental Engineering, Southwest Jiaotong University, Chengdu, China.

Received: 9 April 2014 Accepted: 10 July 2014

Published online: 04 October 2014

\section{References}

Bird JF, Bommer JJ (2004) Earthquake losses due to ground failure. Eng Geol 75(2):147-179

Burchfiel BC, Royden LH, Hilst RD, Hager BH, Chen Z, King RW, Li C, Lü J, Yao H, Kirby E (2008) A geological and geophysical context for the Wenchuan earthquake of 12 May 2008, Sichuan, People's Republic of China. GSA Today 18(7):4-11

Chigira M, Wu XY, Inokuchi T, Wang G (2010) Landslides induced by the 2008 Wenchuan earthquake, Sichuan, China. Geophys J Roy Astron Soc 118(3-4):225-238

China Earthquake Administration (2008). http://www.cea.gov.cn/manage/html/ 8a8587881632fa5c0116674a018300cf/sc/ (last access: 8 July 2014)

Cui P, Zhu YY, Han YS, Chen XQ, Zhuang JQ (2009) The 12 May Wenchuan earthquake-induced landslide lakes: distribution and preliminary risk evaluation. Landslides 6(3):209-223

Huang RQ, Li WL (2009) Development and distribution of geohazards triggered by the 5.12 Wenchuan Earthquake in China. Sci China Ser E-Tech Sci 52(4):810-819

Ishihara K (1993) Liquefaction and flow failure during earthquakes. Geologija 43(3):351-451

Kurahashi S, Irikura K (2010) Characterized source model for simulating strong ground motions during the 2008 Wenchuan earthquake. Bull Seismol Soc Am 100(5B):2450-2475

Li XJ, Zhou ZH, Yu HY, Wen RZ, Lu DW, Huang M, Zhou YN, Cu JW (2008) Strong motion observations and recordings from the great Wenchuan Earthquake. Earthquake Eng Eng Vibratio 7:235-246

Lu M, Li XJ, An XW, Zhao JX (2010) A preliminary study on the near-source strong-motion characteristics of the great 2008 Wenchuan earthquake in China. Bull Seismol Soc Am 100(5B):2491-2507

Okuda S (1984) Features of debris deposits of large slope failures investigated from historical records. Disaster Prev Res Inst Annuals B 27(B-1):353-368

Ouimet WB (2010) Landslides associated with the May 12, 2008 Wenchuan earthquake: Implications for the erosion and tectonic evolution of the Longmen Shan. Tectonophysics 491:244-252

Qi SW, Xu Q, Zhang B, Zhou YD, Lan HX, Li LH (2011) Source characteristics of long runout rock avalanches triggered by the 2008 Wenchuan earthquake, China. J Asian Earth Sci 40(4):896-906

Sassa K (1988) Geotechnical model for the motion of landslides. Special Lecture of 5th International Symposium on Landslides. Landslides 1:37-55

Sassa K (1997) A new intelligent-type dynamic-loading ring-shear apparatus. Landslide News 10:33

Sassa K, Fukuoka H, Wang FW (1997) Mechanism and risk assessment of landslide- triggered-debris flows: lesson from the 1996.12.6 Otari debris flow disaster, Nagano, Japan. In: Cruden DM, Fell R (eds) Landslide Risk Assessment, Proceedings of the international workshop on landslide risk assessment. Honolulu, pp 347-356, 19-21 February

Sassa K, Fukuoka H, Wang G, Ishikawa N (2004) Undrained dynamic-loading ring-shear apparatus and its application to landslide dynamics. Landslides 1(1):7-19

Sato PH, Harp EL (2009) Interpretation of earthquake-induced landslides triggered by the 12 May 2008, M7.9 Wenchuan earthquake in the Beichuan area, Sichuan Province, China using satellite imagery and Google Earth. Landslides 6:153-159

Tang C, Zhu J, Liang J (2009) Emergency Assessment of Seismic Landslide Susceptibility: A Case Study in the 2008 Wenchuan Earthquake Area. Earthquake Eng Eng Vibration 8:207-217

U.S. Geological Survey (2008) http://earthquake.usgs.gov/earthquakes/ eqinthenews/2008/us2008ryan/ (last access: 8 July 2014)

Wang FW, Sassa K, Fukuoka H (2000) Geotechnical simulation test for the Nikawa landslide induced by 1995.1.17 Hyogoken-Nambu earthquake. Soils Found 40(1):35-46
Wang FW, Cheng QG, Highland L, Miyajima M, Wang HB, Yan CG (2009) Preliminary investigations of some large- scale landslides triggered by the 2008 Sichuan earthquake. Landslides 6(1):47-54

Wang D, Xie LL, Abrahamson NA, Li SY (2010) Comparison of Strong Ground Motion from the Wenchuan, Earthquake of 12 May 2008 with the Next Generation Attenuation (NGA) Ground-Motion Models. Bull Seismol Soc Am 100(5B):2381-2395

Xu X, Wen X, Yu G, Chen G, Klinger Y, Hubbard J, Shaw J (2009) Coseismic reverse- and oblique-slip surface faulting generated by the 2008Mw7.9 Wenchuan earthquake, China. Geology 37:515-518

Yi GX, Wen XZ, Wang SW (2006) Study on fault sliding behaviors and strong-earthquake risk of the Longmenshan-Minshan fault zones from current seismicity parameters. Earthquake Res China 22(2):117-125 (in Chinese)

Yin YP, Wang FW, Sun P (2009) Landslide hazards triggered by the 2008 Wenchuan earthquake, Sichuan, China. Landslides 6(2):139-152

Yuan RM, Xu XW, Chen GH, Tan XB, Klinger Y, Xing HL (2010) Ejection Landslide at Northern Terminus of Beichuan Rupture Triggered by the 2008 Mw 7.9 Wenchuan Earthquake. Bull Seismol Soc Am 100(5B):2689-2699

\section{doi:10.1186/s40677-014-0001-6}

Cite this article as: Wang et al:: Key factors influencing the mechanism of rapid and long runout landslides triggered by the 2008 Wenchuan earthquake, China. Geoenvironmental Disasters 2014 1:1.

\section{Submit your manuscript to a SpringerOpen ${ }^{\odot}$ journal and benefit from:}

- Convenient online submission

Rigorous peer review

- Immediate publication on acceptance

- Open access: articles freely available online

- High visibility within the field

- Retaining the copyright to your article

Submit your next manuscript at springeropen.com 